\title{
Phase Formation in Thin Films of Cu-In-S Ternary System
}

\author{
M. A. Nuriyev ${ }^{1}$ \\ ${ }^{1}$ Faculty of Engineering, Nakhchivan State University, Azerbaijan, Nakhchivan, Russia \\ Correspondence: M. A. Nuriyev, Faculty of Engineering, Nakhchivan State University, Azerbaijan, Nakhchivan \\ AZ7000, Russia. Tel: 994-50-317-0369. E-mail: mubariznuri@mail.ru
}

Received: April 4, 2012 Accepted: May 8, 2012 Online Published: June 11, 2012

doi:10.5539/jmsr.v1n3p92 URL: http://dx.doi.org/10.5539/jmsr.v1n3p92

\begin{abstract}
In this paper we present the results of studies on the interaction of thin films of $\mathrm{Cu}-\mathrm{In}-\mathrm{S}$, which is obtained by evaporation of individual components in the plane of condensation, consisting of fresh chips $\mathrm{NaCl}$. Electron-diffraction analysis shows that the length of the regions forming binary compounds and ternary compounds of $\mathrm{CuInS}_{2}$ with simultaneous and sequential deposition of components is the same. Thus we can speak with certainty that the existence of thin film of tetragonal phase of ternary compound is present in $\mathrm{CuInS}_{2}$.
\end{abstract}

Keywords: structural, interactions, phase, films, atoms, lattice, diffractions

\section{Introduction}

$\mathrm{A}^{\mathrm{I}}-\mathrm{B}^{\mathrm{III}}-\mathrm{C}^{\mathrm{VI}}$ chemical group ternary compounds with a particular nano dimensional thin films of $\mathrm{Cu}-\mathrm{In}-\mathrm{S}$ system are promising materials to create photosensih surface barrier structures with big integral sensitivity used by changing solar energy to electric energy (Johan, 2010; Taunier, 2005; Hiroaki, 2005).

This paper deals with the investigated results on study of thin film interaction in Cu-In-S system which detailed study allows the existence of various phases of $\mathrm{Cu}-\mathrm{S}$, In-S systems and ternary compound of $\mathrm{CuInS}_{2}$, compound in filmy state to be revealed. The first evidence for $\mathrm{Cu}-\mathrm{S}$ and $\mathrm{In}-\mathrm{S}$ system state diagrams being double cross-sections of Cu-In-S system is in (Djurle, 1958; Morimoto, 1962; Khansen, 1962; Zargarova, 1967) and (Hogg, 1968) respectively. By interaction between $\mathrm{Cu}$ and $\mathrm{S}$ there have been formed compounds which compositions could be in agreement with the formulae of $\mathrm{Cu}_{2} \mathrm{~S}, \mathrm{Cu}_{1.8} \mathrm{~S}$ being known as chalcousite and dihenite according to existing minerals in nature. The phase of $\mathrm{Cu}_{1.75} \mathrm{~S}$ composition being known as anilite has been established in (Morimoto, 1969). In given system intermediate phases established in (Cook, 1970) are in agreement with $\mathrm{Cu}_{1.92} \mathrm{~S}$ and $\mathrm{Cu}_{\mathrm{x}} \mathrm{S}$ formulae. By In-S system component interaction $\operatorname{In}_{2} \mathrm{~S}, \operatorname{InS}_{2} \operatorname{In}_{6} \mathrm{~S}_{7}, \mathrm{In}_{5} \mathrm{~S}_{6}, \mathrm{In}_{4} \mathrm{~S}_{5}$, $\mathrm{In}_{3} \mathrm{~S}_{4}, \mathrm{In}_{2} \mathrm{~S}_{3}, \mathrm{In}_{3} \mathrm{~S}_{5}$ composition compounds (Khansen, 1962; Zargarova, 1967) and (Hogg, 1968) have been formed.

\section{Experimental Procedure}

The comprehensive researched deals with results studied of thin films of interaction of $\mathrm{Cu}$-İn-S system, which shows the existence of various phases of $\mathrm{Cu}-\mathrm{S}, \mathrm{In}-\mathrm{S}$ in the ternary system of compound $\mathrm{CuInS}_{2}$ composition in the film state to be revealed. To produce samples with continuously changing composition and to prevent $\mathrm{Cu}$ and $\mathrm{S}$ oxidation, re evaporation of films is obtained during the process of subsequent thermal treatment in vacuum have been placed in carbon capsule. Individual components of $\mathrm{Cu}$ and $\mathrm{S}$ have been evaporated in vacuum by pressure of residual gases no more $10^{-4} \mathrm{~Pa}$ from three sources. Limiting tungsten conical helix from which $\mathrm{Cu}$ and In have been evaporated are at distance of $150 \mathrm{~mm}$ from each other at a height of $80 \mathrm{~mm}$ above substrates being at room temperature.

In this paper we analyze the results of studies of phase formation processes in the films of the system $\mathrm{Cu}-\mathrm{In}-\mathrm{S}$, obtained by simultaneous deposition and stratified components of the system. In the process of obtaining thin films were realized in all phases of a single loop in the vacuum system VUP - 4. Phase analysis was performed using films formed on the ESA electronograph production brand EMR-102. In the vacuum system can be obtained films of dissimilar materials, semiconductor - metal, semiconductor-insulator interface, etc. with a certain ratio of components having different thicknesses. Structure and properties of thin films is largely determined by the conditions of condensation and compliance of its structure with the structure of the substrate. It should be noted that the degree of purity and nature of the substrate topography and the surface temperature and the degree of vacuum, the rate of evaporation, molecular beam angle of incidence to the substrate also 
affects the structure and properties of the resulting films.

It should be noted that the presence of contamination greatly affects the electrical properties of the films. In Terms of growth in the film changed, if contamination located on the substrate in the form of small isolated islets from each other. Depending on whether the binding energy between the higher content of the film and contamination of materials or material between the film and the substrate-film form, or on islands or on the exposed portion of the substrate.

Therefore, before spraying had to be done, cleaning the substrate thoroughly as well as protecting them from the appearance of oil films resulting from the penetration of fluids from the vapor and primary diffusion pumps.

There have been newly used made spalls on $\mathrm{NaCl}, \mathrm{KCl}, \mathrm{LiF}$ single crystals and amorphous polyamide celluloid as substrates. The third source from $\mathrm{S}$ is at a height of $90 \mathrm{~mm}$ from condensation plane between sources $\mathrm{Cu}$ and In. In this case on the condensation plane the layer of continuously changing content of components are formed: alloy in this case system includes from 0 up to $100 \%$ copper, from 100 up to $0 \%$ indium and from $100 \%$ sulphur in the center up to $0 \%$ on limiting points of condensation plane, consequently all compound of $\mathrm{Cu}-\mathrm{In}-\mathrm{S}$ system.

\section{Results and Discussion}

Electron diffraction analysis of the layer like this allows the phase composition of component ternary field to be determined. By electron diffraction patterns obtained from the films being in close proximity to the source $\mathrm{Cu}$ there has been established existence of several regions: region of primarily resulting phase of chalcocite $\mathrm{Cu}_{2} \mathrm{~S}$ with rhombic cell periods $\mathrm{a}=1.1881$ nanometers; $\mathrm{b}=2.7323$ nanometers; $\mathrm{c}=1.3494$ nanometers, SYS Ab2m $\left(\mathrm{C}^{15}{ }_{20}\right)$, which undergoes phase transition and goes into hexagonal chalcocite with the periods $\mathrm{a}=0,389$ nanometers; $c=0,668$ nanometers, SYS C6\mmc (Buerger, 1944); region of $\mathrm{Cu}_{2-\mathrm{x}} \mathrm{S}$ face-centered cubic phase with crystal lattice periods $\mathrm{a}=0.560$ nanometers and $\mathrm{Cu}_{7} \mathrm{~S}_{4}$ composition phase with rhombic structure periods $\mathrm{a}=0.789$ nanometers; $\mathrm{b}=0.784$ nanometers; $\mathrm{c}=1.101$ nanometers, SYS Pnma $\left(\mathrm{D}^{16}{ }_{2 \mathrm{~h}}\right.$ ) (Morimoto, 1969); region of $\mathrm{CuS}$ hexagonal phase pure compound with lattice constants $\mathrm{a}=0,3794$ nanometers; $\mathrm{c}=1.6332$ nanometers, SYS $\mathrm{P}_{3} \backslash \mathrm{mmc}$ checking with the data given in (Djurle, 1958) and also their mixtures $\mathrm{Cu}_{7} \mathrm{~S}_{4}$ with $\mathrm{CuS}$.

Phase composition of the films obtained at evaporation from the source In is characteristic of the presence of InS, $\mathrm{In}_{6} \mathrm{~S}_{7}, \mathrm{In}_{2} \mathrm{~S}_{3}, \mathrm{In}_{3} \mathrm{~S}_{5}$ composition amorphous compounds crystallizing in rhombic crystal system with periods $a=0.394$ nanometers; $b=0.444$ nanometers; $c=1.064$ nanometers $P_{n m n}\left(D^{16}{ }_{2 h}\right)$ (Buerger, 1944), monoclinic crystal system with periods $a=0.9090$ nanometers; $b=0.3887$ nanometers; $c=1.7705$ nanometers, SYS P2 $11 \mathrm{~m}$ (Hogg, 1967), cubic crystal system with $a=0.537$ nanometers $\quad$ and hexagonal crystal system with $a=0.5789$ nanometers; $\mathrm{c}=2.030$ nanometers (Aliyev, 1993), respe ctively.

Further films of primarily resulting phase $\alpha-\mathrm{In}_{2} \mathrm{~S}_{3}$ have been annealed at T $313-328 \mathrm{~K}$. Mentioned films undergo thermal treatment within $\mathrm{T} 328 \mathrm{~K}$ for short time 3-5 min. in order significant losses of $\mathrm{S}$ not to be taken place. These films go erreversibly into crystal $\beta$-modification with crystallographic constants a $=1.074$ nanometers, SYS $\mathrm{Fd} 3 \mathrm{~m}-0^{7}{ }_{\mathrm{h}}$. Amorphous film thermal treatment with $\mathrm{S}=4 \pi \sin \theta / \lambda=25.32$ nanometers $^{-1} ; 34.52$ nanometers $^{-1} ; 58.27$ nanometers $^{-1}$ (Figure 1) obtained on the substrates spaced $50-55 \mathrm{~mm}$ and $55-60 \mathrm{~mm}$ apart from $\mathrm{Cu}$ and $\mathrm{In}$ evaporator centers, in the direction of the source $\mathrm{S}$ is exactly in the center of condensation plane that allows polycrystalline $\mathrm{CuInS}_{2}$ (Figure 2) with tetragonal lattice periods a $=0.552$ nanometers; $\mathrm{c}=1.108$ nanometers, SYS I42d $\left(D^{12}{ }_{2 b}\right)(H a h n, 1953)$ and ( Novoselova, 1979) to be revealed, respectively.

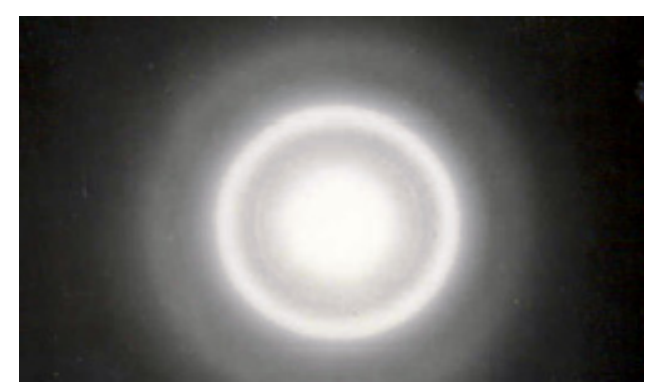

Figure 1. Electron diffraction pattern of captions to the figures amorphous $\mathrm{CuInS}_{2}$ 


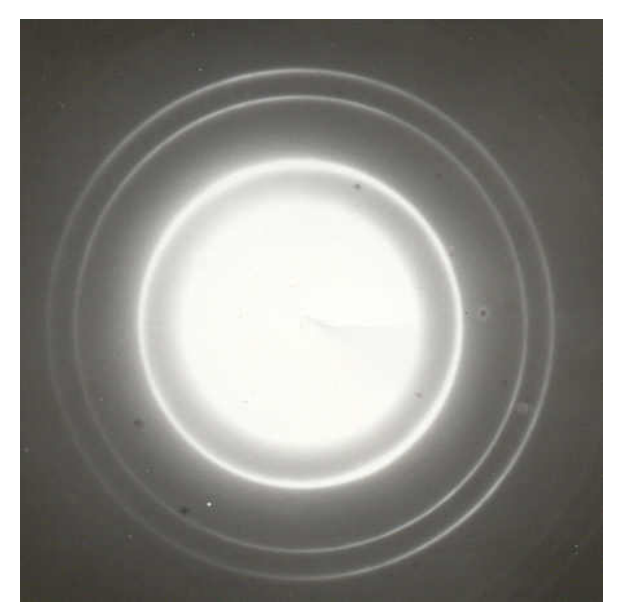

Figure 2. Electron diffraction pattern of polycrystal $\mathrm{CuInS}_{2}$

Further annealing of $\mathrm{CuInS}_{2}$ films at $\mathrm{T}=493 \mathrm{~K}$ and above does not bring about any change in their structure, which electron diffraction patterns are characteristic of the presence diffraction lines of only tetragonal phase. Rate of temperature rise is $20 \mathrm{deg} / \mathrm{min}$; isothermal hold up time is 30 to $40 \mathrm{~min}$.

When considering above-mentioned data on phase formation investigation in Cu-In-S system thin films one can conclude that observed amorphous phase of $\mathrm{CuInS}_{2}$ composition is steady at room temperature. $\mathrm{CuInS}_{2}$ crystal films do not experience transformations within $\mathrm{T}=493 \mathrm{~K}$. It should be noted that at $\mathrm{Cu}$, In and $\mathrm{S}$ deposition in vacuum one layer at a time independent of chemical element deposition order the phase composition of condensation plane (Figure 3) does nor differ from the case of their simultaneous deposition. Extension of resulting double compound regions and $\mathrm{CuInS}_{2}$ composition ternary compound at simultaneous and subsequent depositions of components is similar. Thus one can state with assurance about the existence of only tetragonal phase of $\mathrm{CuInS}_{2}$ composition ternary compound in filmy state.
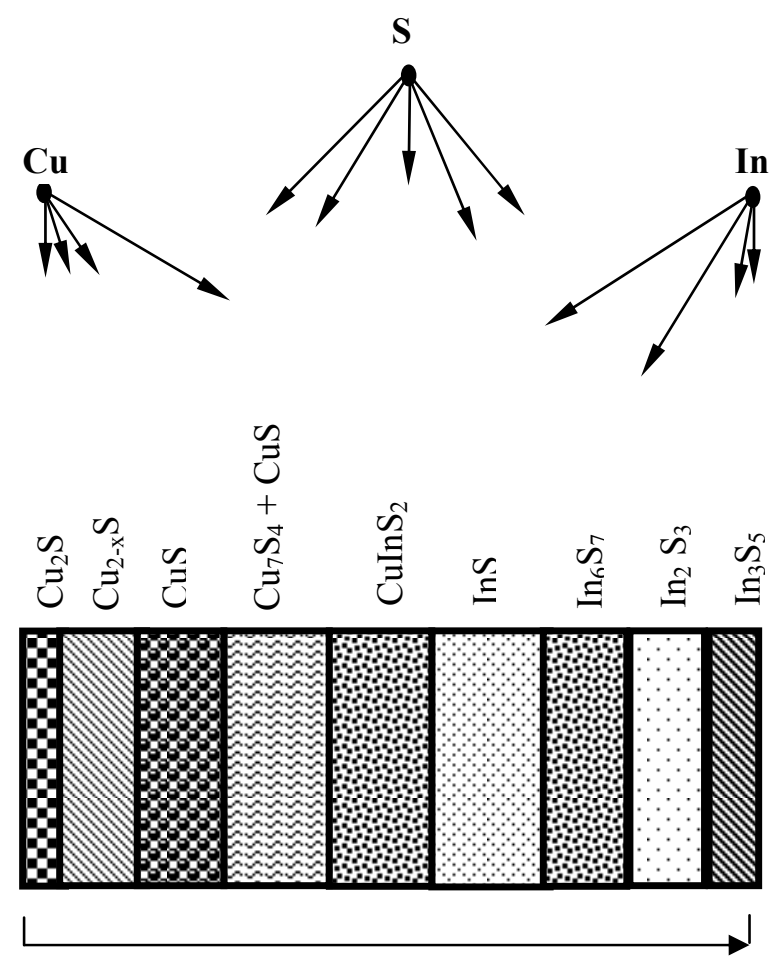

150

Figure 3. Diagram of phase distribution on condensation plane for $\mathrm{Cu}-\mathrm{In}-\mathrm{S}$ system 
When stratified deposition $\mathrm{Cu}-\mathrm{In}-\mathrm{S}$ in a vacuum, regardless of the deposition of chemical elements; the phase composition of the condensation plane is no different from the case of simultaneous deposition. The length of the regions that form binary compounds and ternary compounds of composition $\mathrm{CuInS}_{2}$ at the same time is sequentially deposited in components, which are identical to the phase compositions. $\mathrm{Cu}-\mathrm{S}$ and In-S systems, with sections of the double triple systems $\mathrm{Cu}-\mathrm{In}-\mathrm{S}$ are characterized by crystalline compounds, $\mathrm{Cu}_{2} \mathrm{~S}, \mathrm{Cu}_{2-\mathrm{x}} \mathrm{S}$, $\mathrm{Cu}_{7} \mathrm{~S}_{4}, \mathrm{CuS}$ and mixtures of amorphous phases $\mathrm{InS}, \mathrm{In}_{6} \mathrm{~S}_{7}, \operatorname{In}_{2} \mathrm{~S}_{3}, \operatorname{In}_{3} \mathrm{~S}$ and the presence of the compounds, respectively. Composition of the ternary compound $\mathrm{Cu}$ In $\mathrm{S}_{2}$ is formed in the amorphous state with values $S=4 \pi \sin \theta / \lambda=25,32 ; 34,52 ; 58,27$ nanometers $^{-1}$.

\section{Reference}

Aliyev, F. I. (1993). Interactions, phase formation, structure and crystallization kinetics of thin films of A3-B6. Dis. Dr. Baku, 341.

Buerger, M., \& Buerger, N. (1944). Low-chalcocite and High- chalcocite. Am. Mineral., 29, 55-65.

Cook ,W., Shiozawa, J., \& Augustine, F. (1970). Relationship of Copper Sulfide and Cadmium Phases. J. Appl. Phys., 41(7), 3058-3063. http://dx.doi.org/10.1063/1.1659365

Djurle, S. (1958). An X-ray Study on the System Cu-S. Acta Chem. Scand., 12(7), 1415-1426. http://dx.doi.org/10.3891/acta.chem.scand.12-1415

Hahn, H., \& Klingler, W. (1953). Kristalstructure von $\mathrm{Ga}_{2} \mathrm{Se}_{3}$. Zeitsch. Anorg. Allgem. Chem., 271, 3-4, 153-170.

Hiroaki, Matsushita, \& Akinori, Katsui. (2005). Materials design for Cu-based quaternary compounds derived from chalcopyrite-rule. Journal of Physics and Chemistry of Solids, 66(11), November, 1933-1936. http://dx.doi.org/10.1016/j.jpcs.2005.09.028

Hogg, J., \& Duffin ,W. (1967). The Crystal Structure of $\operatorname{In}_{6} \mathrm{~S}_{7}$. Acta Crystallogr. Bd., 23, 11, 66-69.

Johan, Pohl, \& Karsten, Albe. (2010). Thermodynamics and kinetics of the copper vacancy in $\mathrm{CuInSe}_{2}, \mathrm{CuGaSe}_{2}$, $\mathrm{CuInS}_{2}$, and $\mathrm{CuGaS}_{2}$ from screened-exchange hybrid density functional theory. J. Appl. Phys., 108, 023509. http://dx.doi.org/10.1063/1.3456161

Khansen, M., \& Anderko, K. (1962). Structure of double alloys. M. Metalugizdat., 2, 1488.

Morimoto, N. (1962). Djurleite, a New Copper Sulphide Mineral. Mineral Journ., 3, 5-6, 338-344.

Morimoto, N., Koto, K., \& Shimazaki, J. (1969). Anilite $\mathrm{Cu}_{7} \mathrm{~S}_{4}$, a new Mineral. Am. Mineral., 54, 1256-1268.

Novoselova, A. V., \& Lazarova, K. H. (1979). Physico-chemical properties of semiconductive substances: Reference book. Nauka, 340.

Taunier, S., Sicx-Kurdi, J., Grand, P. P., Chomont, A., Ramdani, O., Parissi, L., Panheleux, P., Naghavi, N., Hubert, C., Ben-Farah, M., Fauvarque, J. P., Connolly, J., Roussel, O., Mogensen, P., Mahé, E., Guillemoles, J. F., Lincot, D., \& Kerrec, O. (2005). Cu(In, Ga) $(\mathrm{S}, \mathrm{Se})_{2}$ solar cells and modules by electrodeposition. Thin Solid Films, 480-481, 1 June, 526-531. http://dx.doi.org/10.1016/j.tsf.2004.11.200

Zargarova, M. I., \& Gamidov, R. S. (1967). About production of several compounds of In and S. Izv. Acad. Of Sci. USSR. Series Non-organic materials, 3(6), 1085-1086. 